Vol 3, No. 1, Agustus 2020: 200 -212, DOI: https://doi.org/10.34007/iehss.v3i1.261

\title{
Perlindungan Hukum Bagi Korban Hubungan Seksual Sedarah (Studi Pada Unit Perlindungan Perempuan Dan Anak SATReskrim Polrestabes Medan)
}

\section{Legal Protection For Victims Concerned Sexual Relationship (Study at the SATReskrim Women's and Children's Protection Unit Medan Polrestabes)}

\author{
Dhoory Vinevera Sigiro*, Suhaidi \& Ibnu Affan \\ Program Pasca Sarjana, Program Studi Ilmu Hukum, Fakultas Hukum \\ Universitas Islam Sumatera Utara, Indonesia.
}

Diterima: 23 Juli 2020 ; Disetujui : 02 Agustus 2020 ; Dipublish : 04 Agustus 2020 *Corresponding Email: Dhoorv12@gmail.com

\begin{abstract}
Abstrak
Tujuan penelitian ini adalah mendeskripsikan peran unit perlindungan perempuan dan anak Satreskrim Polrestabes Medan dalam memberikan perlindungan hukum terhadap korban hubungan seksual sedarah dan hambatan unit perlindungan perempuan dan anak satreskrim polrestabes Medan dalam hal penanganan hukum kasus hubungan seksual sedarah. Penelitian ini merupakan penelitian yuridis normatif yang didukung dengan penelitian yuridis empiris. Penelitian ini bersifat deskriptif analisis, yaitu melukiskan obyek atau peristiwanya tanpa suatu maksud untuk mengambil kesimpulan-kesimpulan yang berlaku umum. Sumber data penelitian ini terdiri dari data primer dan data sekunder, berupa bahan hukum primer, sekunder dan tersier. Analisis yang digunakan dalam penelitian ini yaitu analisis data kualitatif. Berdasarkan hasil penelitian diperoleh, pengaturan hubungan seksual sedarah dalam berbagai undang-undang yang berlaku saat ini masih menekankan pada bentuk hubungan seksual sedarah yang dilakukan dengan anak. Sedangkan hubungan seksual sedarah yang didasari pada persetujuan kedua belah pihak bagi mereka yang telah dewasa belum diatur secara khusus. Peran unit perlindungan perempuan dan anak Satreskrim Polrestabes Medan dalam memberikan perlindungan hukum terhadap korban hubungan seksual sedarah, dengan mengupayakan terlaksananya hak-hak korban. Hambatan unit Perlindungan Perempuan Dan Anak Satreskrim Polrestabes Medan dalam hal penanganan hukum kasus hubungan seksual sedarah belum adanya hubungan yang saling bersinergi antar lembaga-lembaga yang ada.
\end{abstract}

Kata Kunci: Perlindungan Hukum, Korban, Seksual Sedarah.

\begin{abstract}
This research is a normative juridical study supported by empirical juridical research. This research is analytical descriptive, that is, describing an object or event without an intention to draw conclusions that are generally accepted. The data source of this research consists of primary data and secondary data, in the form of primary, secondary and tertiary legal materials. The analysis used in this study is qualitative data analysis. Based on the research results obtained, the regulation of incest in a variety of laws currently in force still emphasizes the form of incest committed by a child. Whereas incest is based on the agreement of both parties for those who are adults has not been specifically regulated. The role of the Satreskrim Polrestabes Medan women's and child protection unit in providing legal protection for victims of incest, by seeking the rights of victims. Obstacles to the Protection Unit of Women and Children of the Satreskrim Medan District Police in terms of legal handling of incest in the case of sexual intercourse in the absence of synergic relations between the existing institutions.
\end{abstract}

Keywords: Legal Protection, Victims, Sexual Inclusion.

How to Cite: Sigiro, D.V, Suhaidi, \& Affan, I (2020). Perlindungan Hukum Bagi Korban Hubungan Seksual Sedarah (Studi Pada Unit Perlindungan Perempuan Dan Anak Satreskrim. Journal of Education, Humaniora and Social Sciences (JEHSS). 3 (1): 200-131.

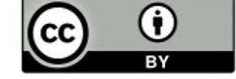

This work is licensed under a Creative Commons Attribution 4.0 


\section{PENDAHULUAN}

Undang-Undang Negara Republik Indonesia Nomor 23 Tahun 2002 Tentang Perlindungan Anak (selanjutnya disebut Undang-Undang Perlindungan Anak). Hubungan seksual sedarah, dilihat dari aspek hukum pidana termasuk perbuatan atau tindak pidana terhadap kesusilaan sebagaimana diatur dalam Bab XIV Buku II KUHP yang memuat kejahatan terhadap kesusilaan yang tersebar pada Pasal 281 sampai dengan Pasal 303 KUHP. Di dalamnya yang dimaksud dengan kesusilaan sebagian besar berkaitan dengan seksualitas (Soesilo, 2017).

Dalam Pasal 429 RUU KUHP ayat (2) menyebutkan bahwa tindak pidana persetubuhan dengan anggota keluarga sedarah dalam garis lurus atau ke samping sampai derajat ketiga. Ancaman pidananya antara 3 hingga 12 tahun. Jika yang menjadi korban adalah anak-anak dibawah 18 tahun, hukuman maksimalnya ditambah menjadi tiga tahun lagi. Walaupun belum berlaku tetapi dasar hukum tersebut dapat menjadi acuan dalam penjatuhan pidana kepada terdakwa (Artika, 2008).

Secara khusus, larangan melakukan hubungan seksual terhadap anak telah diatur UndangUndang Perlindungan Anak, yang mengatur mengenai tindak pidana pencabulan terhadap anak dimana ancaman pidananya lebih berat dari pada pasal-pasal yang diatur dalam KUHP, yaitu paling lama 15 tahun. Hal ini dapat dilihat dalam rumusan Pasal 82 Undang-Undang Perlindungan Anak, yang menyebutkan:

Setiap orang yang dengan sengaja melakukan kekerasan atau ancaman kekerasan, memaksa, melakukan tipu muslihat, serangkaian kebohongan atau membujuk anak untuk melakukan atau membiarkan dilakukan perbutan cabul di pidana penjara paling lama 15 (lima belas) tahun dan paling singkat 3 (tiga) tahun dan denda paling banyak Rp 300.000.000,00 (tiga ratus juta rupiah) dan paling sedikit Rp 60.000.000,00 (enam puluh juta rupiah) (Pasal 82 Undang-Undang Nomor 23 Tahun 2002 Tentang Perlindungan Anak yang telah dilakukan perubahan dengan UndangUndang Nomor 35 Tahun 2014 Tentang Perubahan Atas).

Hubungan seksual sedarah dalam hal anak sebagai korban kejahatan, maka tentunya anak sebagai korban perlu untuk mendapatkan perlindungan. Perlindungan hukum bagi anak sebagai korban kekerasan dan kejahatan, termasuk kejahatan seksual yang terjadi terhadap anak adalah penting, mengingat anak merupakan generasi penerus bangsa. Perlindungan terhadap perempuan, khususnya anak sebagai korban hubungan seksual sedarah begitu penting.

Berkenaan dengan perlindungan korban, Barda Nawawi Arief dalam Lilik Mulyadi, memberikan penjelasan sebagai berikut: Perlindungan korban dapat dilihat dari dua makna, yaitu: perlindungan hukum untuk tidak menjadi korban tindak pidana (berarti perlindungan Hak Asasi Manusia atau kepentingan hukum seseorang) dan perlindungan untuk memperoleh jaminan/santunan hukum atas penderitaan/kerugian orang yang telah menjadi korban tindak pidana (jadi identik dengan penyantunan korban). Bentuk santunan itu dapat berupa pemulihan nama baik (rehabilitasi), pemulihan keseimbangan bathin (antara lain pemaafan), pemberian ganti rugi (restitusi, kompensasi, jaminan/santunan kesejahteraan sosial) dan sebagainya (Mulyadi, 2004).

Berdasarkan hasil pengambilan data awal penulis pada unit perlindungan perempuan dan anak Satreskrim Polrestabes Medan, ditemukan kasus pencabulan atau hubungan seksual sedarah, yang dilakukan oleh seorang bapak kandung (MD) terhadap anak kandungnya yang masih di bawah umur (JQ), yang terjadi sekitar tanggal 20 April 2019 dirumah pelaku yang beralamat Jl. Kemiri II Simpang Limun Kec. Medan Kota.

\section{HASIL DAN PEMBAHASAN}

Peran Unit Perlindungan Perempuan dan Anak Satreskrim Polrestabes Medan Dalam Memberikan Perlindungan Hukum Terhadap Korban Hubungan Seksual Sedarah

Pembicaraan mengenai korban kejahatan tidak dapat terlepas dari ilmu viktimologi. Viktimologi berasal dari bahasa latin "Victima" yang berarti korban dan "logos" yang berarti ilmu. Secara terminologi viktimologi berarti suatu studi yang mempelajari tentang korban, penyebab 
Dhoory Vinevera Sigiro, Suhaidi \& Ibnu Affan, Perlindungan Hukum Bagi Korban Hubungan Seksual

timbulnya korban dan akibat-akibat penimbulan korban yang merupakan masalah manusia sebagai kenyataan social (Arief dan Gultom, 2011).

Viktimologi, berasal dari bahasa latin "victim" yang berarti korban dan logos yang berarti ilmu. Secara terminologis, viktimologi berarti suatu studi yang mempelajari tentang korban penyebab timbunya korban dan akibat-akibat penimbulan korban yang merupakan masalah manusia sebagai suatu kenyataan social (Yulia, 2010).

Pengertian Viktimologi mengalami tiga fase perkembangan. Pada awalnya, viktimologi hanya mempelajari korban kejahatan saja. Pada fase ini dikatakan sebagai penal or special viktimology. Pada fase kedua, viktimologi tidak hanya mengkaji masalah korban kejahatan saja. Pada fase ini disebut sebagai general victimology. Fase ketiga, viktimologi sudah berkembang lebih luas lagi yaitu mengkaji permasalahan korban penyalahgunaan kekuasaan dan hak-hak asasi manusia, pada fase ini dikatakan sebagai new victimology (Yulia, 2010).

Viktimologi memberikan pengertian yang lebih baik tentang korban kejahatan sebagai hasil perbuatan manusia yang menimbulkan penderitaan mental, fisik, dan sosial. Tujuannya adalah untuk memberikan penjelasan mengenai peran yang sesungguhnya para korban dan hubungan mereka dengan para korban serta memberikan keyakinan dan kesadaran bahwa setiap orang mempunyai hak mengetahui bahaya yang dihadapi berkaitan dengan lingkungannya, pekerjaannya, profesinya dan lain-lainnya.

Berbicara tentang korban kejahatan, maka paradigma yang ada tidak terlepas dari pengaruh viktimologi. Melalui viktimologi diketahui berbagai aspek yang berkaitan dengan korban, seperti: faktor penyebab munculnya kejahatan, bagaimana seseorang dapat menjadi korban, upaya mengurangi terjadinya korban kejahatan, hak dan kewajiban korban kejahatan (Arief dan Gultom, 2011).

Aristoteles mengatakan bahwa manusia adalah "zoon politicon", makhluk sosial atau makhluk bermasyarakat, oleh karena tiap anggota masyarakat mempunyai hubungan antara satu dengan yang lain (Soeroso, 2016). Sebagai makhluk sosial maka sadar atau tidak sadar manusia selalu melakukan perbuatan hukum (rechtshandeling) dan hubungan hukum (rechtsbetrekkingen) tiap-tiap perbuatan hukum tersebut membutuhkan perlindungan hukum atau perlindungan dari hukum. C.S.T. Kansil, menjelaskan: Perlindungan hukum adalah penyempitan arti dari perlindungan, dalam hal ini hanya perlindungan oleh hukum saja. Perlindungan yang diberikan oleh hukum, terkait pula dengan adanya hak dan kewajiban, dalam hal ini yang dimiliki oleh manusia sebagai subyek hukum dalam interaksinya dengan sesama manusia serta lingkungannya. Sebagai subyek hukum manusia memiliki hak dan kewajiban untuk melakukan suatu tindakan hukum (Kansil, 2006).

Solly Lubis, lebih lanjut menjelaskan perlindungan hukum berarti "perlindungan yang diberikan oleh hukum (legal protection) terhadap sesuatu status (kedudukan) ataupun hak, misalnya: hak milik, hak pilih, hak berusaha, hak khusus warga negara, dan sebagainya" (Lubis, 2011).

Perlindungan hukum erat kaitannya dengan kepastian hukum, yakni kejelasan peraturan hukum mengenai hak, kewajiban dan status seseorag atau suatu badan hokum (Simanjuntak, 2010; Rahmi, 2018; Ritonga, 2019). Kepastian hak, kewajiban dan kepastian status ini mendatangkan ketertiban, karena dengan adanya kejelasan seperti diatur oleh hukum, maka seseorang tahu benar-benar bagaimana status atau kedudukannya, seberapa jauh hak maupun kewajibannya dalam kedudukan tersebut.

Beberapa faktor yang tidak menunjang kepastian dan perlindungan hukum, antara lain:

1. Sikap tidak responsif dari pembuat aturan hukum, baik perencanaan (drafting), maupun pembuat keputusan (decision) dan akhirnya pelaksanaan (enforcement) serta penindakan setiap pelanggarannya (punishment).

2. Tiadanya kesadaran dan ketaatan yang sesungguhnya dari semua pihak, baik pihak pencari keadilan maupun pihak aparat sebagai penegak keadilan, serta warga masyarakat seluruhnya.

3. Sikap tidak adil dan obyektif dari aparat penegak hukum dan penegak keadilan (Lubis, 2011).

Berdasarkan pendapat sarjana tesebut di atas, dapat dipahami bahwa yang dimaksud dengan perlindungan hukum adalah perlindungan yang diberikan oleh hukum (legal protection) Ww http://mahesainstitute.web.id/ojs2/index.php/jehss

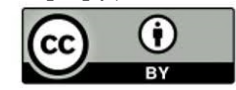

This work is licensed under a Creative Commons Attribution 4.0 
terhadap sesuatu status (kedudukan) ataupun hak, misalnya: hak milik, hak pilih, hak berusaha, hak khusus warga negara, dan sebagainya. Perlindungan hukum erat kaitannya dengan kepastian hukum, maka perlindungan hukum hanya dapat dicapai jika telah ada aturan hukum yang mengatur tentang hak-hak individu, atau kelompok dalam suatu aturan perundang-undangan.

Upaya penanggulangan kejahatan merupakan bagian dari upaya perlindungan terhadap masyarakat, yaitu melalui kebijakan kriminal adalah merumuskan peraturan perundangundangan oleh pembuat undang-undang (legislatif). Dengan demikian, dapat dikatakan bahwa kebijakan perlindungan korban kejahatan hakekatnya merupakan bagian integral yang tidak dapat dipisahkan dari kebijakan hukum pidana. Berdasarkan konsep tersebut, peran Negara guna meciptakan suatu kesejahteraan sosial sebagaimana amanat UUD 1945 dan Pancasila, tidak hanya terbatas pada pemenuhan kebutuhan-kebutuan materiil dari warga negaranya, tetapi lebih dari itu, diperlukan penegakan hukum yang mempunyai aspek perlindungan kepada korban kejahatan guna terpenuhinya rasa keadilan dan kepastian hukum dalam kehidupan bernegara. Kebijakan hukum pidana yang berkaitan dengan perlindungan hukum terhadap korban kejahatan perdagangan orang dapat dilihat dalam beberapa peraturan perundang-undangan, diantaranya: 1. Kitab Undang-Undang Hukum Pidana (KUHP).

Secara umum, KUHP telah memberikan perlindungan kepada korban, yakni berupa adanya ketentuan penggantian kerugian yang diderita korban oleh pelaku kejahatan melalui ketetapan hakim dalam menjatuhkan pidana bersyarat atau sebagai pengganti pidana pokok. Sekalipun KUHP mencantumkan aspek perlindungan korban kejahatan berupa pemberian ganti kerugian, namun ketentuan ini tidak luput dari berbagai kendala dalam pelaksanaannya, yaitu:

a. Penetapan ganti rugi tidak dapat diberikan oleh hakim sebagai sanksi yang berdiri sendiri disamping pidana pokok, jadi hanya sebagai "syarat khusus" untuk dilaksanakannya atau dijalaninya pidana pokok yang dijatuhkan kepada terpidana.

b. Penetapan syarat khusus berupa ganti kerugian ini hanya dapat diberikan apabila hakim menjatuhkan pidana paling lama satu tahun atau pidana kurungan.

c. Syarat khusus berupa ganti rugi ini pun menurut KUHP hanya bersifat fakultatif, tidak bersifat imperatif.

2. Undang-Undang No. 8 Tahun 1981 tentang Hukum Acara Pidana (KUHAP).

Selama ini berkembang pendapat yang menyebutkan dengan diperiksa dan diadilinya pelaku kejahatan, telah melindungi korban kejahatan secara tidak langsung karena pelaku kejahatan tidak akan lagi mengganggu masyarakat/korban, namun pelaku kejahatan tidak cukup hanya bertanggung jawab secara pidana/dihukum tetapi juga harus bertanggung jawab secara keperdataan supaya semakin menambah efek jera sekaligus bertanggung jawab secara pribadi kepada korban.

KUHAP mengatur beberapa hak-hak dari korban kejahatan, yang dapat dipergunakan oleh korban dalam proses peradilan pidana. Hak-hak tersebut antara lain:

a. Hak untuk melakukan kontrol terhadap penyidik dan penuntut umum, terhadap tindakan penghentian penyidikan dan/atau penuntutan. Hal ini penting untuk diberikan guna menghindari adanya upaya dari pihak-pihak tertentu dengan berbagai motif (politik, uang, dan sebagainya) yang bermaksud menghentikan proses pemeriksaan, karena bagaimanapun juga dalam suatu proses pemeriksaan pidana, sekalipun pelaku/tersangka berhadapan dengan negara yang diwakili oleh jaksa penuntut umum, tetapi korban sebagai pihak pelapor dan/atau yang menderita kerugian tetap berkepentingan atas pemeriksaan tersebut.

b. Hak korban kejahatan yang berkaitan dengan kedudukannya sebagi saksi. Kesaksian dari (saksi) korban sangat penting untuk memperoleh suatu kebenaran materil, oleh karena itu, untuk mencegah korban mengundurkan diri sebagai saksi perlu sikap proaktif dari aparat penegak hukum untuk memberikan jaminan keamanan bagi korban dan keluarganya pada saat mengajukan diri sebagai saksi.

c. Hak untuk menuntut ganti kerugian yang diderita akibat kejahatan. Hak ini dimaksudkan untuk memberikan kemudahan kepada korban suatu tindak pidana dalam mengajukan gugatan ganti kerugian, yaitu melalui cara percepatan proses pemberian ganti kerugian 
Dhoory Vinevera Sigiro, Suhaidi \& Ibnu Affan, Perlindungan Hukum Bagi Korban Hubungan Seksual

kepada pihak korban kejahatan atau keluarganya oleh tersangka melalui penggabungan perkara pidananya dengan gugatan ganti kerugian. Perlu kiranya diketahui bahwa permintaan penggabungan perkara gugatan ganti kerugian hanya dapat diajukan selambat-lambatnya sebelum penuntut umum mengajukan tuntutan pidana, atau jika penuntut umum tidak hadir maka permintaan tersebut diajukan selambat-lambatnya sebelum hakim menjatuhkan putusan.

d. Hak bagi keluarga korban untuk mengijinkan atau tidak mengijinkan polisi melakukan otopsi.

e. Mengijinkan atau tidak mengijinkan polisi untuk melakukan otopsi juga merupakan suatu bentuk perlindungan korban kejahatan, mengingat masalah otopsi ini bagi beberapa kalangan sangat erat kaitannya dengan masalah agama, adat istiadat, serta aspek kesusilaan/kesopanan lainnya.

3. Undang-Undang No. 26 Tahun 2000 tentang Peradilan Hak Asasi Manusia.

Perlindungan korban sebagai akibat dari terjadinya pelanggaran hak asasi manusia yang berat telah diatur dalam Undang-undang No. 26 Tahun 2000 tentang Peradilan Hak Asasi Manusia berupa perlindungan fisik dan mental terhadap saksi dan korban dalam pelanggaran Hak Asasi Manusia, dari ancaman, gangguan, teror, dan kekerasan dari pihak manapun.

Perlindungan yang diberikan pada korban atau saksi ini dapat diberikan pada tahap penyelidikan, penyidikan, penuntutan dan atau pemeriksaan di sidang pengadilan, atas dasar inisiatif dari aparat penegak hukum dan aparat keamanan dan atau dari permohonan yang disampaikan oleh korban.

Bentuk perlindungan hukum lainnya adalah dalam bentuk pemberian kompensasi, restitusi dan rehabilitasi kepada korban. Khusus mengenai pemberian restitusi terhadap korban kejahatan, Soedjono Dirjosisworo berpendapat: "Namun, mengenai restitusi betapapun akan sukar dilaksanakan karena apabila apa yang harus diterima korban dari pelaku atau orang ketiga tidak dapat dipenuhi karena ketidakmampuan yang benar-benar dapat dibuktikan atau karena pelaku tidak rela membayar sebab ia harus menjalani pidana yang berat" (Dirdjosisworo, 2002).

4. Undang-Undang No. 23 Tahun 2002 tentang Perlindungan Anak jo Undang-Undang No. 35 Tahun 2014 Tentang Perubahan Atas Undang-Undang No. 23 Tahun 2002 Tentang Perlindungan Anak.

Banyaknya kasus kekerasan seksual menjadikan anak sebagai korbannya. Dalam beberapa tahun terakhir kejahatan seksual terhadap anak mengalami peningkatan. Hal ini menunjukkan indikator buruknya kualitas perlindungan anak di Indonesia. Keberadaan anak yang belum mampu untuk hidup mandiri tentunya sangat membutuhkan orang-orang sebagai tempat berlindung. Rendahnya kualitas perlindungan anak, banyak menuai kritik dari berbagai elemen masyarakat. Bahkan dalam beberapa kasus kejahatan seksual terhadap anak justeru dilakukan oleh orang-orang terdekat dalam lingkungan keluarga, seperti: abang, kakak, paman, bahkan dilakukan oleh Ayah kandung.

Pertanyaan yang sering dilontarkan adalah sejauh mana pemerintah telah berupaya memberikan perlindungan hukum kepada anak sehingga anak dapat memperoleh jaminan atas kelangsungan hidup dan penghidupannya sebagai bagian dari hak asasi manusia. Sesuai dengan ketentuan Undang-Undang No. 23 Tahun 2002 tentang Perlindungan Anak, negara mempunyai kewajiban menyelenggarakan perlindungan terhadap anak. Negara dalam hal ini adalah (pemerintah) sebagai refresentasi dari negara dalam menjalankan fungsinya menyelenggarakan sistem pemerintahan. Selain itu, tanggung jawab terhadap perlindungan anak juga tidak terlepas dari peran serta masyarakat, keluarga dan orang tua.

5. Undang-Undang No. 31 Tahun 2014 tentang Perubahan Atas Undang-Undang No. 13 Tahun 2006 tentang Perlindungan Saksi dan Korban

Dasar pertimbangan perlunya Undang-Undang yang mengatur perlindungan korban kejahatan (dan saksi) untuk segera disusun dengan jelas dapat dilihat pada bagian menimbang dari Undang-Undang No. 13 Tahun 2006, yang antara lain menyebutkan: "Penegak hukum sering mengalami kesukaran dalam mencari dan menemukan kejelasan tentang tindak pidana yang dilakukan oleh pelaku karena tidak dapat menghadirkan saksi dan/atau korban disebabkan adanya ancaman, baik fisik maupun psikis dari pihak tertentu".

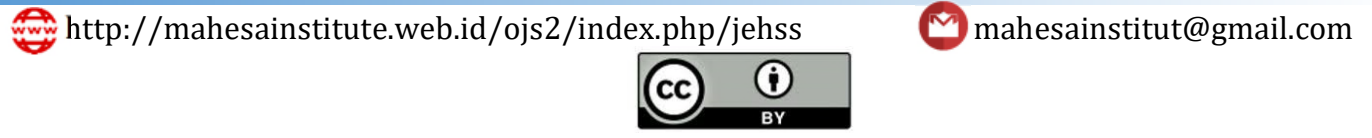

204

This work is licensed under a Creative Commons Attribution 4.0 
Vol 3, No. 1, Agustus 2020: 200 -212, DOI: https://doi.org/10.34007/iehss.v3i1.261

Saat saksi dan/atau korban akan memberikan keterangan, tentunya harus disertai jaminan bahwa yang bersangkutan terbebas dari rasa takut sebelum, pada saat dan setelah memberikan kesaksian. Hal inilah yang menjadi tujuan dari Undang-Undang No. 13 Tahun 2006 tentang Perlindungan Saksi dan Korban sebagaimana telah diubah dengan Undang-Undang No. 31 Tahun 2014 tentang Perubahan Atas Undang-Undang No. 13 Tahun 2006 tentang Perlindungan Saksi dan Korban. Dalam Undang-Undang ini, juga diatur adanya Lembaga Perlindungan Saksi dan Korban atau yang dapat disingkat dengan LPSK yaitu lembaga yang bertugas dan berwenang untuk memberikan perlindungan dan hak-hak lain kepada saksi dan/atau korban.

Korban kejahatan yang pada dasarnya merupakan pihak yang paling menderita dalam suatu tindak pidana, tidak memperoleh perlindungan sebanyak yang diberikan undang-undang kepada pelaku kejahatan. Akibatnya, setelah pelaku kejahatan telah dijatuhi sanksi pidana oleh pengadilan, kondisi korban tidak diperdulikan. Perlindungan hukum korban kejahatan seksual (hubungan seksual sedarah) yang dilakukan oleh orang tua kandung merupakan bagian dari perlindungan terhadap masyarakat, yang dapat diwujudkan dalam berbagai bentuk atau model.

Beberapa bentuk atau model perlindungan yang dapat diberikan kepada korban, antara lain (Mansur \& Gultom, 2008.):

a. Pemberian Restitusi dan Kompensasi.

Setiap korban atau ahli warisnya berhak memperoleh restitusi dari pelaku. Restitusi ini merupakan ganti kerugian atas kehilangan kekayaan atau penghasilan, penderitaan, biaya untuk tindakan perawatan medis dan atau psikologis serta kerugian lain yang diderita korban sebagai akibat perdagangan orang. Dilihat dari kepentingan korban dalam konsep ganti rugi terkandung dua manfaat, yaitu untuk memenuhi kerugian materiil dan segala biaya yang telah dikeluarkan dan merupakan pemuasan emosional korban. Adapun dilihat dari sisi kepentingan pelaku, kewajiban mengganti kerugian dipandang sebagai suatu bentuk pidana yang dijatuhkan dan dirasakan sebagai suatu yang konkret dan langsung berkaitan dengan kesalahan yang diperbuat pelaku. Selain restitusi, kompensasi dapat digunakan sebagai bentuk lain perlindungan korban tindak pidana sebagai danti kerugian yang diberikan oleh Negara. Ganti kerugian oleh Negara tersebut merupakan suatu pembayaran pelayanan kesejahteraan, karena Negara bertanggung jawab dan berkewajiban secara moral untuk melindungi masyarakatnya.

b. Layanan Konseling dan Pelayanan Medis.

Pelayanan yang konseling dan medis yang diberikan kepada korban yang menderita akibat suatu tindak pidana, antara lain pendampingan konseling, pengobatan dan laporan tertulis atau visum.

c. Bantuan Hukum.

d. Pemberian Informasi.

Pemberian restitusi terhadap korban perdagangan orang merupakan bagian dari kebijakan hukum pidana yang diterapkan terhadap pelaku tindak pidana perdagangan orang disamping pelaksanaan hukuman pidana bagi pelaku. Pelaksanaan pemberian restitusi terhadap korban dilaksanakan berdasarkan Peraturan Pemerintah No. 44 Tahun 2008 Tentang Pemberian Kompensasi, Restitusi, dan Bantuan Kepada Saksi dan Korban. Pasal 20 Peraturan Pemerintah No. 44 Tahun 2008 Tentang Pemberian Kompensasi, Restitusi, dan Bantuan Kepada Sanksi dan Korban, menyatakan bahwa:

1) Korban tindak pidana berhak memperoleh Restitusi.

2) Permohonan untuk memperoleh Restitusi sebagaimana dimaksud pada ayat (1) diajukan oleh Korban, Keluarga, atau kuasanya dengan surat kuasa khusus.

3) Permohonan untuk memperoleh Restitusi sebagaimana dimaksud pada ayat (2) diajukan secara tertulis dalam bahasa Indonesia di atas kertas bermeterai cukup kepada pengadilan melalui LPSK.

Permohonan restitusi dapat dilakukan sebelum atau setelah pelaku dinyatakan bersalah berdasarkan putusan pengadilan yang telah memperoleh kekuatan hukum. Permohonan restitusi memuat sekurang-kurangnya:

a. Identitas pemohon; 
Dhoory Vinevera Sigiro, Suhaidi \& Ibnu Affan, Perlindungan Hukum Bagi Korban Hubungan Seksual

b. Uraian tentang tindak pidana;

c. Identitas pelaku tindak pidana;

d. Uraian kerugian yang nyata-nyata diderita; dan

e. Bentuk restitusi yang diminta.

Permohonan restitusi yang diajukan oleh korban atau ahli warisnya ataupun kuasanya ke LPSK harus melampirkan berkas-berkas sebagai berikut:

a. Fotokopi identitas Korban yang disahkan oleh pejabat yang berwenang;

b. Bukti kerugian yang nyata-nyata diderita oleh Korban atau Keluarga yang dibuat atau disahkan oleh pejabat yang berwenang;

c. Bukti biaya yang dikeluarkan selama perawatan dan/atau pengobatan yang disahkan oleh instansi atau pihak yang melakukan perawatan atau pengobatan;

d. Fotokopi surat kematian dalam hal Korban meninggal dunia;

e. Surat keterangan dari Kepolisian Negara Republik Indonesia yang menunjukkan pemohon sebagai Korban tindak pidana;

f. Surat keterangan hubungan Keluarga, apabila permohonan diajukan oleh Keluarga; dan

g. Surat kuasa khusus, apabila permohonan Restitusi diajukan oleh kuasa Korban atau kuasa Keluarga.

Apabila permohonan restitusi sebagaimana dimaksud pada Ayat (1) perkaranya telah diputus pengadilan dan telah memperoleh kekuatan hukum tetap, permohonan restitusi harus dilampiri kutipan putusan pengadilan tersebut.

\section{Perlindungan Hukum Korban Hubungan Seksual Sedarah}

Keseriusan pemerintah mengatasi rmasalah perlindungan korban dapat dilihat dari sikap pemerintah membuat dan menerbitkan regulasi tentang perlindungan saksi dan korban, yaitu dengan diterbitkannya Undang-undang Nomor 13 Tahun 2006 tentang Perlindungan Saksi dan Korban. Namun, seiring berjalannya waktu undang-undang tersebut dianggap belum mengakomodir permasalahan perlindungan terhadap terhadap korban, karena didalam undangundang masih terdapat beberapa kelemahan yang dinilai cukup signifikan, sehingga perlu dilakukan perubahan (Penjelasan Undang-Undang Republik Indonesia Nomor 31 Tahun 2014 tentang Perubahan Atas Undang-Undang Nomor 13 Tahun 2006 tentang Perlindungan Saksi dan Korban).

Berdasarkan pada pertimbangan tersebut di atas, maka kemudian pemerintah menerbitkan Undang-undang Nomor 31 Tahun 2014 yang merupakan Perubahan atas Undang-Undang No. 13 Tahun 2006 mengenai Perlindungan Saksi dan Korban yang disahkan oleh Pemerintah dan diundangkan untuk memperbaiki kelemahan pada Undang-Undang No. 13 Tahun 2006 tentang Perlindungan Saksi dan Korban.

Khusus untuk perlindungan hukum terhadap anak, negara memberikan perhatian dengan mengesahkan Undang-undang Nomor 35 Tahun 2014 yang merupakan Perubahan atas Undangundang Nomor 23 Tahun 2002 mengenai Perlindungan Anak. Perubahan tersebut untuk mempertegas pentingnya pemberatan sanksi pidana dan denda bagi pelaku kejahatan terhadap anak, yang bertujuan untuk memberikan efek jera serta mendorong adanya langkah konkret untuk memulihkan kembali kedudukan anak secara fisik, psikis dan juga sosial, dalam hal anak sebagai korban dan atau anak sebagai pelaku kejahatan, sekaligus sebagai langkah antisipatif agar anak sebagai korban atau sebagai pelaku tidak menjadi pelaku kejahatan yang sama di kemudian hari (Penjelasan Undang-Undang Republik Indonesia Nomor 35 Tahun 2014 tentang Perubahan Atas Undang-Undang Nomor 23 Tahun 2002 tentang Perlindungan Anak).

Berdasarkan ketentuan Undang-Undang Perlindungan Saksi dan Korban yang baru, terdapat beberapa perubahan dari undang-undang sebelumnya didalam pengaturan mengenai hak-hak dari saksi dan korban, perubahan tersebut menjadi sebagai berikut (Undang-Undang Negara Republik Indonesia Nomor 31 Tahun 2014 Tentang Perubahan Atas Undang-Undang Nomor 13 Tahun 2006 Tentang Saksi dan Korban): 
1. Mendapatkan perlindungan untuk keamanan pribadi, Keluarga, dan juga harta bendanya, serta bebas dari Ancaman yang berkenaan dengan kesaksiannya yang akan, sedang, atau telah diberikan;

2. Ikut serta di dalam proses memilih dan juga menentukan bentuk perlindungan dan juga dukungan keamanan;

3. Memberikan keterangan tanpa mendapat tekanan;

4. Memperoleh penerjemah;

5. Bebas dari pertanyaan-pertanyaan yang menjerat;

6. Mendapatkan informasi yang berkaitan dengan perkembangan kasus;

7. Mendapatkan informasi yang berkaitan dengan putusan pengadilan;

8. Mendapatkan informasi dalam hal-hal terpidana dibebaskan;

9. Dirahasiakan segala yang berkaitan dengan identitasnya;

10. Mendapatkan sebuah identitas baru;

11. Mendapatkan sebuah tempat kediaman sementara;

12. Mendapatkan sebuah tempat kediaman baru;

13. Memperoleh penggantian biaya untuk transportasi sesuai dengan kebutuhan;

14. Mendapatkan nasihat hukum;

15. Mendapatkan bantuan biaya hidup untuk sementara sampai batas waktu Perlindungan Berakhir; dan/atau

16. Mendapatkan pendampingan.

Berdasarkan ketentuan di atas, korban kekerasan seksual, termasuk kekerasan seksual yang dilakukan dalam lingkup keluarga berhak untuk mendapatkan hak-haknya yang secara umum diatur dalam Pasal 5 Undang-Undang No. 31 Tahun 2014 tentang Perubahan Atas Undang-Undang No 13 Tahun 2006 tentang Perlindungan Saksi dan Korban.

Perlindungan yang diberikan dimaksudkan bahwa setiap anak dalam lingkungan sosialnya berhak mendapatkan perlindungan. Dalam hal anak yang menjadi korban dari tindak kekerasan seksual, dalam hal ini Undang-Undang Nomor 35 Tahun 2014 tentang Perubahan Atas UndangUndang Nomor 23 Tahun 2002 Tentang Perlindungan Anak memberikan perlindungan khusus dalam hal pemulihan korban yang diatur dalam Pasal 64A serta pengajuan ganti rugi (restitusi) terhadap diri korban secara langsung yang ditanggungkan kepada pelaku tindak kekerasan seksual yang diatur dalam Pasal 71D.

Undang-Undang Nomor 35 Tahun 2014 tentang Perubahan Atas Undang-Undang Nomor 23 Tahun 2002 tentang Perlindungan Anak berisi tentang larangan-larangan melakukan perbuatan yang melanggar hak-hak anak yang diatur dalam BAB XIA yang terdiri dari Pasal 76A-76D yang berisi perbuatan-perbuatan yang dilarang dilakukan terhadap anak. Khusus untuk larangan melakukan tindak kekerasan seksual diatur dalam Pasal 76D dan 76E.

Berdasarkan ketentuan di atas, maka ketika terjadi pelanggaran hukum oleh seseorang dimana orang tersebut telah melanggar hak-hak anak, sebab telah melakukan kekerasan seksual maupun penyimpangan seksual terhadap anak, orang tersebut harus mempertanggungjawabkan perbuatan dan harus dikenakan sanksi (hukuman) sesuai dengan rumusan delik pidana yang sesuai dengan perbuatannya. Dalam hal ini diatur Pasal 81 dan Pasal 82 pada BAB XII tentang Ketentuan Pidana dalam Undang-Undang Perlindungan Anak.

Di samping diatur dalam Undang-Undang Nomor 35 Tahun 2014 tentang Perubahan Atas Undang-Undang Nomor 23 Tahun 2002 Tentang Perlindungan Anak, perlindungan anak juga diatur dalam Undang-Undang No. 24 Tahun 2003 tentang Penghapusan Kekerasan Dalam Rumah Tangga (yang selanjutnya disebut Undang-Undang KDRT).

Undang-Undang KDRT merupakan bentuk perundang-undangan hukum positif Indonesia yang didalamnya mengatur tentang penghapusan kekerasan dalam rumah tangga yang salah satu tujuannya memberikan perlindungan bagi anak selain perempuan. Undang-Undang KDRT, anak dalam rumah tangga mendapat perlindungan melalui larangan kekerasan yang tercantum pada BAB III dan secara khusus menjelaskan adanya larangan kekerasan seksual dalam rumah tangga (anak) yang secara tegas diatur pada Pasal 5 berbunyi: 
Setiap orang dilarang melakukan kekerasan dalam rumah tangga terhadap orang dalam lingkup rumah tangganya, dengan cara:

1. Kekerasan fisik;

2. Kekerasan psikis;

3. Kekerasan seksual; atau

4. Penelantaran rumah tangga.

Undang-Undang KDRT menjelaskan bahwa anak merupakan salah satu bagian dari rumah tangga oleh karenanya larangan-larangan kekerasan seperti yang telah tercantum dalam Pasal 5 juga ditujukan terhadap anak. Dengan demikian undang-undang ini secara jelas telah memberikan perlindungan terhadap anak khusus dalam lingkup rumah tangga ketika anak mendapat kekerasan selama dalam lingkungan rumah tangga.

Pasal 11 Undang-Undang No. 23 Tahun 2004 tentang Penghapusan Kekerasan Dalam Rumah Tangga berbunyi: "Pemerintah bertanggung jawab dalam upaya pencegahan kekerasan dalam rumah tangga". Dan masing-masing tugas pemerintah dan masyarakat secara terperinci dijelaskan dalam Pasal 12-15 undang-undang tersebut yang sebenarnya bertujuan untuk menunjukkan peran penting dalam mengupayakan pencegahan kekerasan dalam rumah tangga (anak).

Pemberian perlindungan korban kekerasan seksual dalam rumah tangga diatur dalam Pasal 27 Undang-Undang KDRT, yang berbunyi: "Dalam hal korban adalah anak, laporan dapat dilakukan oleh orang tua, wali, pengasuh, atau anak yang bersangkutan yang dilaksanakan sesuai dengan ketentuan peraturan perundang-undangan yang berlaku". Selain diatur dalam Pasal 27, perlindungan terhadap anak sebagai korban kekerasan seksual diatur pula dalam Pasal 46, Pasal 47 dan Pasal 48 Undang-Undang PKDRT.

Anak korban kekerasan seksual juga mendapatkan perlindungan di dalam proses peradilan menurut Undang-Undang No. 11 Tahun 2011 tentang Sistem Peradilan Pidana Anak. Di dalamnya terdapat pasal-pasal mengenai perlindungan terhadap hak-hak anak korban dalam proses beracara diantaranya:

Pasal 18 Undang-Undang No. 11 Tahun 2011 Tentang Sistem Peradilan Pidana Anak, Pasal ini mengatur bahwa dalam menangani perkara Anak, Anak Korban, dan/atau Anak Saksi, Pembimbing Kemasyarakatan, Pekerja Sosial rofesional dan Tenaga Kesejahteraan Sosial, Penyidik, Penuntut Umum, Hakim, dan Advokat atau pemberi bantuan hukum lainnya wajib memperhatikan kepentingan terbaik bagi Anak dan mengusahakan suasana kekeluargaan tetap terpelihara.

Pasal 19 Undang-Undang No. 11 Tahun 2011 Tentang Sistem Peradilan Pidana Anak. Pasal mengatur bahwa identitas Anak, Anak Korban, dan/atau Anak Saksi wajib dirahasiakan dalam pemberitaan di media cetak ataupun elektronik Identitas tersebut meliputi nama Anak, nama Anak Korban, nama Anak Saksi, nama orang tua, alamat, wajah, dan hal lain yang dapat mengungkapkan jati diri Anak, Anak Korban, dan/atau Anak Saksi.

Aturan-aturan hukum yang dijelaskan di atas, merupakan bentuk perlindungan hukum terhadap anak yang secara substansial diatur dalam berbagai peraturan perundang-undangan di Indonesia. Undang-undang mengatur beberapa hak-hak yang wajib diperoleh oleh anak dan juga mengatur perbuatan-perbuatan yang tidak boleh dilakukan terhadap anak, termasuk melakukan hubungan seksual dengan cara dan bentuk apapun.

Adanya regulasi mengenai perlindungan terhadap anak-anak dalam berbagai undangundang, maka merupakan pelaksanaan dari upaya pencegahan (preventif) untuk menghindarkan anak-anak dari berbagai tindak kekerasan maupun kejahatan yang dilakukan oleh orang dewasa, termasuk kejahatan atau penyimpangan seksual. Di samping itu, regulasi mengenai larangan terhadap berbagai perbuatan yang tidak boleh dilakukan terhadap anak yang disertai dengan ancaman pidana merupakan instrumen bagi penegak hukum untuk melakukan upaya refresif terhadap pelaku kejahatan atau penyimpangan seksual terhadap anak.

\section{Peran Unit PPA Satreskrim Polrestabes Medan Dalam Memberikan Perlindungan Hukum} Terhadap Korban Hubungan Seksual Sedarah

Polri memiliki peranan penting dalam mewujudkan keamanan dan kenyamanan dalam kehidupan bermasyarakat, Polri merupakan lembaga pengayom masyarakat dalam segala kondisi wh http://mahesainstitute.web.id/ojs2/index.php/jehss

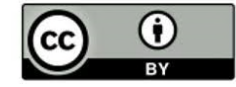


sosial yang caruk maruk. Peran Polri dapat dikatakan sebagai aspek kedudukan yang berhubungan dengan kedudukanya sebagai pelindung masyarakat (Suparlan, 2008).

Peran yang dilakukan oleh Unit PPA Satreskrim Polrestabes Medan dalam memberikan perlindungan terhadap korban hubungan seksual sedarah yang dilakukan terhadap anak di bawah umur, dilakukan dengan mengupayakan terlaksananya hak-hak korban dan hak-hak anak sebagai korban sebagaimana telah ditetapkan dalam Undang-Undang (Wawancara dengan Mesra Hati Sembiring, Panit PPA Polrestabes Medan, pada tanggal 12 November 2019).

Pada tahap awal, maka perlu menjaga keamanan anak sebagai korban dari berbagai ancaman kejahatan yang mungkin terjadi dan mengancam diri anak tersebut. Oleh karena itu, penyidik menetapkan pihak-pihak tertentu yang dapat dipercaya dan dianggap bertanggung jawab sebagai wali dari anak tersebut (Wawancara dengan Yuki Amelia, Penyidik pada Unit PPA Polrestabes Medan, pada tanggal 12 November 2019). Di dalam proses pemeriksaan terhadap korban, maka anak wajib didampingi oleh orang tuanya atau walinya. Dalam kasus pencabulan yang dilakukan oleh ayah kandung (MD) terhadap anak kandungnya (AQ) sesuai Laporan Pol No. LP/928/K/IV/2019/SPKT Restabes Medan, tertanggal 08 Mei 2019, maka korban selama proses pemeriksaan senantiasa didampingi oleh neneknya (wali) yang bernama (NT). Untuk mendapatkan jaminan keamanan, maka korban tinggal di rumah neneknya (Wawancara dengan Haspon Winton, Pekerja Sosial Perlindungan Anak Kota Medan, tanggal 9 November 2019).

Peran lain yang dilakukan oleh Unit PPA Satreskrim Polrestabes Medan adalah melakukan penegakan hukum terhadap pelaku. Hasil penyelidikan sebagai dasar untuk dilakukannya penyidikan lebih lanjut karena diduga perbuatan terlapor tesebut dapat terpenuhi dugaan tindak pidana persetubuhan dan atau perbuatan cabul terhadap anak sebagaimana dimaksud dalam Pasal 81 ayat (1), (2), (3) Jo Pasal 76 D Undang-Undang No. 23 Tahun 2002 tentang Perlindungan Anak jo Undang-Undang No. 35 Tahun 2014 tentang Perubahan Undang-Undang No. 23 Tahun 2002 tentang Perlindungan Anak jo Peraturan Pemerintah Pengganti Undang-Undang No. 1 Tahun 2016 tentang Perubahan kedua Atas Undang-Undang No. 23 Tahun 2002 tentang Perlindungan Anak menjadi Undang-Undang.

Hasil gelar perkara dan penyidikan, meliputi pemeriksaan terhadap tersangka, saksi-saksi, dapat disimpulkan bahwa perbuatan tersangka telah memenuhi unsur-unsur pidana sebagaimana pasal-pasal yang disangkakan terhadap tersangka dengan didukungan oleh dua alat bukti yang sah, yakni empat orang saksi dan bukti visum et repertum No.125/OBG/2019, tertanggal 30 April 2019 dengan No. MR : 01. 08. 53. 83 yang dilakukan oleh dokter pemerintah Rumah Sakit Umum Daerah Pringadi Medan.

Berdasarkan uraian di atas, dipahami bahwa Unit PPA Satreskrim Polrestabes Medan memiliki peran dalam memberikan perlindungan terhadap korban hubungan seksual, khususnya terhadap anak sebagai korban adalah dengan memberikan dan melaksanakan hak-hak korban dan hak-hak anak sebagai korban sebagaimana diatur dalam peraturan undang-undangan yang berlaku.

Penegakan hukum pidana dalam kedudukannya sebagai hukum pidana materiil tidak dapat terlepas dari peran hukum pidana formal, yang bertujuan untuk menegakan keseluruhan hukum pidana materiil yang telah ditetapkan dalam berbagai undang-undang. Di Indonesia, ketentuan hukum pidana formal telah ditetapkan dalam Undang-Undang Republik Indonesia Nomor 8 Tahun 1981 tentang Kitab Undang-Undang Hukum Acara Pidana (selanjutnya disebut KUHAP). Oleh karena itu, setiap proses peradilan pidana yang dimulai dari penyelidikan, penyidikan, penuntutan dan pemeriksaan di muka persidangan sampai saat ini tetap mengacu kepada ketentuan KUHAP.

Penegakan hukum pidana terhadap berbagai kejahatan yang terjadi di masyarakat dalam sistem peradilan pidana di Indonesia diawali dari penyelidikan dan penyidikan yang merupakan kewenangan Kepolisian Republik Indonesia. Rangkaian panjang dalam proses peradilan pidana di Indonesia berawal dari suatu proses yang dinamakan penyelidikan.

Apabila hasil dari penyelidikan tersebut penyelidik menyimpulkan bahwa telah terjadi suatu tindak pidana (delict), maka statusnya akan ditingkatkan pada tahap penyidikan yang ditujukan untuk mencari bukti dan menemukan tersangkanya. Selanjutnya, penyidik apabila telah 
menemukan bukti permulaan yang cukup dan mengarah kepada seseorang sebagai tersangkanya dapat dilakukan penangkapan terhadap tersangka dan penahanan.

Proses lebih lanjut setelah dilakukan penyidikan adalah pelimpahan perkara dari penyidik ke Kejasaksaan untuk segera dilakukannya pemeriksaan di muka persidangan. Berkenaan dengan tindak pidana perbuatan cabul terhadap anak kandung yang dilakukan oleh pelaku (MD) terhadap anaknya sendiri (AQ), telah dilakukan pelimpahan perkara ke Kejaksaan Negeri Medan berdasarkan Surat No. B/10375/VIII/Res. 1. 4/2019/Reskrim, tertanggal 15 Agustus 2019.

\section{Hambatan Unit Perlindungan Perempuan dan Anak Satreskrim Polrestabes Medan Dalam Hal Penanganan Hukum Kasus Hubungan Seksual Sedarah}

Pelaksanaan perlindungan hukum terhadap korban, termasuk perlindungan hukum terhadap korban hubungan seksual sedarah pada dasarnya tidaklah dapat dilakukan oleh Penegak hukum saja, dalam hal ini dilakukan oleh Unit Perlindungan Perempuan Dan Anak Satreskrim Polrestabes Medan. Untuk melaksanakan hak-hak korban secara komperehensif sebagaimana diatur dalam Undang-Undang Perlindungan Saksi dan Korban dan juga Undang-Undang Perlindungan Anak, dalam hal anak sebagai korban, maka dibutuhkan sinergitas dari lembagalembaga terkait yang berfungsi memenuhi hak-hak korban.

Secara umum, Unit Perlindungan Perempuan Dan Anak Satreskrim Polrestabes Medan tidak menemukan hambatan yang signifikan dalam memberikan perlindungan hukum terhadap anak korban hubungan seksual sedarah. Secara substansial mekanisme perlindungan hukum terhadap korban telah diatur dalam peraturan perundang-undangan (Wawancara dengan Mesra Hati Sembiring, Panit PPA Polrestabes Medan, pada tanggal 12 November 2019). Akan tetapi, dalam hal-hal tertentu yang membutuhkan kerjasama dengan lembaga terkait. Hubungan ini belum terjalin dengan baik, sehingga terkadang terjadi discomunication, karena belum adanya sinergitas antar lembaga didalam upaya memberikan perlindungan hukum secara maksimal terhadap korban (Wawancara dengan Mesra Hati Sembiring, Panit PPA Polrestabes Medan, pada tanggal 12 November 2019).

Perlindungan korban, khususnya anak sebagai korban kejahatan seksual pada dasarnya bukan saja menjadi tanggung jawab dari penegak hukum, melainkan menjadi tanggung jawab bersama. Oleh karena itu, Untuk terlaksananya perlindungan pada anak dengan maksimal, maka perlu adanya koordinasi kerjasama antara pemerintah, masyarakat dan juga keluarga atau orang tua (Wawancara dengan Mesra Hati Sembiring, Panit PPA Polrestabes Medan, pada tanggal 12 November 2019). Dalam hal kejahatan seksual yang dilakukan oleh orang tua atau dalam lingkup keluarga, maka kedudukan anak disini sangatlah rentan menjadi korban. Sebab, orangtua yang seyogyanya memberikan perlindungan terhadap anak, justreru melakukan tindak pidana atau menodai anaknya sendiri. Di sinilah efek pencegahan sangat sulit dilakukan, karena orang yang paling berwenang untuk melakukan pengawasan dan perlindungan terhadap anak adalah orang tua sendiri.

Di satu sisi, terhadap anak sebagai korban kejahatan, Undang-Undang Perlindungan Anak mengamanatkan dilakukannya perlindungan secara khusus terhadap anak. Perlindungan secara khusus adalah suatu bentuk perlindungan yang dapat diterima oleh Anak dalam situasi dan kondisi tertentu seorang anak untuk mendapatkan jaminan sebuah rasa aman terhadap ancaman yang dapat membahayakan dirinya dan jiwanya dalam tumbuh kembangnya (Pasal 1 Angka 15 Undang- Undang No. 35 Tahun 2014 tentang Perubahan Atas Undang-Undang No. 23 Tahun 2002 tentang Perlindungan Anak).

Bentuk perlindungan khusus yang dapat diberikan pada anak yang menjadi korban suatu tindak pidana dilakukan melalui penanganan yang cepat, termasuk pengobatan dan/atau rehabilitasi secara fisik, psikis, dan sosial, serta pencegahan penyakit dan gangguan kesehatan lainnya; pendampingan dari psikososial pada saat pengobatan sampai dengan saat pemulihan; pemberian sebuah bantuan sosial bagi Anak yang mana berasal dari Keluarga tidak mampu; dan pemberian sebuah perlindungan dan juga pendampingan pada setiap proses peradilan berjalan (Pasal 59 A Undang- Undang No. 35 Tahun 2014 tentang Perubahan Atas Undang-Undang No. 23 Tahun 2002 tentang Perlindungan Anak) 
Vol 3, No. 1, Agustus 2020: 200 -212, DOI: https://doi.org/10.34007/iehss.v3i1.261

Perlindungan Khusus bagi Anak korban dari tindak pidana kejahatan seksual dilakukan melalui upaya (Pasal 69 A Undang- Undang No. 35 Tahun 2014 tentang Perubahan Atas UndangUndang No. 23 Tahun 2002 tentang Perlindungan Anak.)

1. Edukasi mengenai kesehatan reproduksi, nilai-nilai agama, dan juga nilai-nilai kesusilaan;

2. Rehabilitasi social pada anak;

3. Pendampingan psikososial pada saat pengobatan sampai dengan saat pemulihan; dan juga

4. Pemberian sebuah perlindungan dan juga pendampingan pada setiap tingkat pemeriksaan mulai dari proses penyidikan, proses penuntutan, sampai dengan proses pemeriksaan di sidang pengadilan.

Perlindungan pada Anak sebagai korban kejahatan. Oleh karena itu hak-hak anak diatas menjadi sangatlah penting untuk dilindungi, terutama bagi anak korban kejahatan seksual. Dihukumnya seorang pelaku kejahatan seksual tidak menghilangkan rasa-rasa traumatis yang diderita korban (Nurini Aprilianda, Perlindungan Anak Korban Kekerasan Seksual Melalui Pendekatan Keadilan Restoratif, (Arena Hukum Volume 10, Nomor 2, Agustus 2017), h. 309-332). Dalam anak menjadi korban kejahatan seksual, maka perlu adanya hukuman yang berat bagi pelaku, karena anak akan mengalami trauma yang berkepanjangan atas kejahatan seksual yang telah dilakukan oleh orang tua ataupun orang-orang terdekatnya.

\section{SIMPULAN}

Pengaturan hubungan seksual sedarah dalam berbagai undang-undang yang berlaku saat ini masih menekankan pada bentuk hubungan seksual sedarah yang dilakukan dengan anak. Sedangkan hubungan seksual sedarah yang didasari pada persetujuan kedua belah pihak bagi mereka yang telah dewasa belum diatur secara khusus, baik dalam KUHP maupun undang-undang khusus lainnya. Hanya saja dalam RUKHP, hubungan seksual yang didasari pada persetujuan telah diakomodir, sehingga hubungan seksual sedarah tidak saja dilakukan terhadap anak di bawah umur, tetapi termasuk pula terhadap anak yang telah dewasa.

Peran Unit Perlindungan Perempuan dan Anak Satreskrim Polrestabes Medan dalam memberikan perlindungan hukum terhadap korban hubungan seksual sedarah, dengan mengupayakan terlaksananya hak-hak korban. Khusus anak sebagai korban kejahatan seksual, maka disamping terlaksananya hak-hak korban yang diatur dalam Pasal 5 Undang-Undang No. 31 Tahun 2014, juga harus pula terpenuhi hak-hak anak sebagai korban sebagaimana diatur dalam Undang-Undang Perlindungan Anak.

Hambatan Unit Perlindungan Perempuan Dan Anak Satreskrim Polrestabes Medan dalam hal penanganan hukum kasus hubungan seksual sedarah, tidak terdapat hambatan yang signifikan. Hanya saja dalam keadaan tertentu, di mana dibutuhkannya adanya kerjasama dengan lembagalembaga terkait dalam upaya perlindungan terhadap korban, khususnya anak sebagai korban kejahatan yang membutuhkan pendampingan medis maupun sosial sejak awal belum dapat dilaksanakan dengan baik. Hal ini dikarenakan belum adanya hubungan yang saling bersinergi antar lembaga-lembaga yang ada.

\section{DAFTAR PUSTAKA}

Aprilianda, N. (2017), Perlindungan Anak Korban Kekerasan Seksual Melalui Pendekatan Keadilan Restoratif, (Arena Hukum Volume 10, Nomor 2, Agustus 2017).

Arief, D.M. dan Gultom, E. (2011), Urgensi Perlindungan Korban Kejahatan, Antara Norma dan Realita, PT. Raja Grafindo Utama, Jakarta.

Dirdjosisworo, S, (2002), Pengadilan Hak Asasi Manusia Indonesia, Bandung: Citra Aditya Bakti.

Kansil, C.S.T. (2006), Pengantar Ilmu Hukum dan Tata Hukum Indonesia, Jakarta: Balai Pustaka.

Lubis, S. (2011), Serba Serbi Politik Hukum, Medan: PT. Sofmedia.

Marpaung, L. (2005), Asas-Teori-Praktik Hukum Pidana, Jakarta: Sinar Grafika.

Mertokusumo, S, (2007), Mengenal Hukum Suatu Pengantar, Yogyakarta; Liberty.

Muladi, (2008), Kapita Selekta Sistem Peradilan Pidana, Semarang; Universitas Diponegoro.

Mulyadi, L. (2004), Kapita Selekta Hukum Pidana Kriminologi \& Viktimologi, Jakarta: Djembatan.

R. Soeroso, 2016, Pengantar Ilmu Hukum, Jakarta: Sinar Grafika. 
Dhoory Vinevera Sigiro, Suhaidi \& Ibnu Affan, Perlindungan Hukum Bagi Korban Hubungan Seksual

Rahmi, A. (2018). Urgensi Perlindungan Bagi Korbankekerasan Seksual Dalam Sistem Peradilan Pidana Terpadu Berkeadilan Gender. JURNAL MERCATORIA, 11(1), 37-60. doi:https://doi.org/10.31289/mercatoria.v11i1.1499

Ritonga, M. S., Mulyadi, M. \& Mustamam (2019). Penerapan Restorative Justice Sebagai Model Perlindungan terhadap Anak (Studi Penanganan Perkara Anak Berhadapan dengan Hukum pada Wilayah Hukum Pengadilan Negeri Dumai Kelas IA). Journal of Education, Humaniora and Social Sciences (JEHSS). 2 (2): 318-334.

Simanjuntak, M., Januari S., dan Isnaini, (2010), Peran Polri dalam Penyidikan Tindak Pidana Kekerasan Seksual dalam Rumah Tangga (Studi di Unit Perlindungan Perempuan dan Anak Sat Reskrim Polresta Tebing Tinggi), Mercatoria, 3 (2):102-116

Soesilo, R. (2017), Kitab Undang-Undang Hukum Pidana dan Penjelasannya, Bogor; Politiea.

Suparlan, P, (2008), Ilmu Kepolisian, Jakarta: YPKIK.

Yulia, R. (2010). Viktimologi Perlindungan Hukum Terhadap Korban Kejahatan, Graha Ilmu, Yogyakarta.

Undang-Undang Republik Indonesia Nomor 31 Tahun 2014 tentang Perubahan Atas Undang-Undang Nomor 13 Tahun 2006 tentang Perlindungan Saksi dan Korban.

Undang-Undang Republik Indonesia Nomor 35 Tahun 2014 tentang Perubahan Atas Undang-Undang Nomor 23 Tahun 2002 tentang Perlindungan Anak.

Undang-Undang Negara Republik Indonesia Nomor 31 Tahun 2014 Tentang Perubahan Atas UndangUndang Nomor 13 Tahun 2006 Tentang Saksi dan Korban.

Pasal 1 Angka 15 Undang- Undang No. 35 Tahun 2014 tentang Perubahan Atas Undang-Undang No. 23 Tahun 2002 tentang Perlindungan Anak.

Pasal 59 A Undang- Undang No. 35 Tahun 2014 tentang Perubahan Atas Undang-Undang No. 23 Tahun 2002 tentang Perlindungan Anak.

Pasal 69 A Undang- Undang No. 35 Tahun 2014 tentang Perubahan Atas Undang-Undang No. 23 Tahun 2002 tentang Perlindungan Anak.

Pasal 82 Undang-Undang Nomor 23 Tahun 2002 Tentang Perlindungan Anak yang telah dilakukan perubahan dengan Undang-Undang Nomor 35 Tahun 2014 Tentang Perubahan Atas Undang-Undang Negara Republik Indonesia Nomor 23 Tahun 2002 Tentang Perlindungan Anak. 